\title{
Chickpea production in response to fertilization with zinc and doses of phosphorus
}

\author{
Jorge Henrique dos Santos Fonseca ${ }^{\circledR}$, Maria Nilfa Almeida Neta*® ${ }^{\circledR}$, Rodinei Facco Pegoraro ${ }^{\circledR}$, \\ Gbison Ferreira de Almeida ${ }^{\mathbb{0}}$, Cândido Alves da Costa ${ }^{\circledR}$, Elaine Soares de Almeida ${ }^{\circledR}$
}

Federal University of Minas Gerais, Montes Claros, Brazil

*Corresponding author, e-mail: marianilfa@gmail.com

\begin{abstract}
Chickpea cultivation in Brazil has not yet been consolidated, and studies aiming at the adequate nutritional management for this crop are necessary. This work aimed to evaluate the production of chickpea plants (cultivar BRS Aleppo) subjected to fertilization with zinc and $P$ doses. The experimental was completely randomized, with four replications, in a $3 \times 5$ factorial scheme, corresponding to three fertilization treatments with $\mathrm{Zn}$ (without $\mathrm{Zn}$ addition; $50 \%$ of $\mathrm{Zn}$ applied at sowing, via soil $+50 \%$ applied at flowering, via leaves; and $100 \%$ applied at sowing, via soil) and five doses of phosphorus $\left(0,60,120,180\right.$, and $240 \mathrm{~kg} \mathrm{ha}^{-1}$ of $\mathrm{P}_{2} \mathrm{O}_{5}$ ). The 100-grain mass (M100), pod mass (MV), number of pods (NV), number of grains (NG), total grain mass (MGT), yield (PROD), dry matter of the shoot part (MSPA) and plant residues (MSRV), and agronomic efficiency (EA) were characterized. There was an isolated effect of the P doses on the M100, MGT, PROD, MSPA, and MSRV characteristics. The application of 240 $\mathrm{kg} \mathrm{ha}^{-1}$ resulted in an increase in the production components and a maximum yield of $3,018 \mathrm{~kg} \mathrm{ha}^{-1}$, indicating the need to adopt higher doses of $\mathrm{P}_{2} \mathrm{O}_{5}$ to increase chickpea production in tropical soils. However, the highest agronomic efficiency was obtained after the application of $60 \mathrm{~kg} \mathrm{ha}^{-1}$ of $\mathrm{P}_{2} \mathrm{O}_{5^{\prime}}$ along with $\mathrm{Zn}$ at sowing.
\end{abstract}

Keywords: Cicer arietinum L., phosphate monoammonium, yield, agronomic efficiency (EA)

\section{Introduction}

Chickpea (Cicer arietinum L.) is a legume species of importance to both human and animal feeding (Laranjo et al., 2014) for presenting a high protein content in its grains. It is the third most cultivated legume species in the world, with 14.5 million tons and a mean yield of $0.96 \mathrm{tha}^{-1}$ (FAO, 2017). It presents high adaptability, being cultivated in semiarid regions with low production cost and presenting the ability to fix atmospheric nitrogen (Nascimento et al., 2016; Canci \& Toker, 2009).

The cultivation of this species in Brazil is incipient, still requiring importation (Avelar et al., 2018; Nascimento et al., 2016). With incentives for the cultivation of this legume in the Brazilian Cerrado region, as recommended by Artiaga et al. (2015), Avelar et al. (2018), Pegoraro et al. (2018), and Hoskem et al. (2017), high yield values were obtained (above $2.000 \mathrm{~kg} \mathrm{ha}^{-1}$ ) in irrigated chickpea crops in the semiarid region of the state of Minas Gerais.
The consolidation of chickpea cultivation in Brazil depends on the definition of balanced nutritional management. The supply of phosphorus (P), a macromolecular constituent of nucleic acids (Marschner, 2012), is essential for the initial root growth, being responsible to aid in the formation of symbiosis with $\mathrm{N}_{2}$-fixing bacteria, promote greater nodulation and root development (Balai et al., 2017; Neenu et al., 2014). Neenu et al. (2014) recommend $60 \mathrm{~kg} \mathrm{ha}^{-1}$ of $\mathrm{P}$ for chickpea crops in India, endorsing the importance of supplementary fertilization with phosphate fertilizers for a higher yield of this grain. In tropical soils, there is a high $\mathrm{P}$ adsorption capacity by oxidic soils, hindering its management and absorption by the plants (Vilar et al., 2010; Novais \& Smyth, 1999) and demanding the application of higher doses of $\mathrm{P}_{2} \mathrm{O}_{5}$ in order to increase production. In that regard, Pegoraro et al. (2018) obtained maximum agronomic efficiency for chickpea in the semiarid region of Minas Gerais after the 
application of $150 \mathrm{~kg} \mathrm{ha}^{-1}$ of $\mathrm{P}_{2} \mathrm{O}_{5}$.

The application of higher $\mathrm{P}$ doses can reduce the availability of zinc (Zn), favoring the formation of poorly soluble complexes in the soil and the interior of the plants, reducing its absorption by roots and accumulation in the shoot part (Marschner, 2012), requiring Zn supplementation through soil or foliar fertilization. Balai et al. (2017), in India, report that the application of $40 \mathrm{~kg} \mathrm{ha}^{-1}$ of $\mathrm{P}$ and $6 \mathrm{~kg} \mathrm{ha}^{-1}$ of $\mathrm{Zn}$ provides a yield of $1.588 \mathrm{~kg} \mathrm{ha}^{-1}$ in chickpea.

However, the importance of studies on the interaction between these elements is evident, aiming at the definition of the nutritional management in this legume and the consolidation of the crop in the semiarid region of Brazil, since the research on the interaction between P and $\mathrm{Zn}$ is still scarce in Brazilian tropical soils. This work aimed to evaluate the production of chickpea subjected to fertilization with zinc and doses of $P$.

\section{Material and Methods}

The study was performed in the municipality of Montes Claros-MG, in an experimental area located in the coordinates $16^{\circ} 40^{\prime} 35^{\prime \prime} \mathrm{S}$ and $43^{\circ} 50^{\prime} 55^{\prime \prime}$ ' W, with $684 \mathrm{~m}$ of elevation and Aw climate, according to the classification by Köppen-Geiger, characterized by dry winter and rainy summer.

The soil of the area was characterized as a Haplic Cambisol, from which 20 simple samples were collected to form a compound sample for the physical and chemical characterization, at the depth from 0 to $20 \mathrm{~cm}$ : Organic matter: $7.37 \mathrm{dag} \mathrm{kg}^{-1} ; \mathrm{pH}\left(\mathrm{H}_{2} \mathrm{O}\right)$ : 5.5; P (Mehlich 1): 2.93 $\mathrm{mg} \mathrm{dm}{ }^{-3} ; \mathrm{K}$ (Mehlich 1): $76 \mathrm{mg} \mathrm{dm}^{-3}$; Ca: $7.3 \mathrm{cmol}_{\mathrm{c}} \mathrm{dm}^{-3}$; Mg: $3.46 \mathrm{cmol}_{\mathrm{c}} \mathrm{dm}^{-3}, \mathrm{Al}(\mathrm{KCl}): 0.04 \mathrm{cmol}_{\mathrm{c}} \mathrm{dm}^{-3} ; \mathrm{H}+\mathrm{Al}: 3.95$ $\mathrm{cmol}_{\mathrm{c}} \mathrm{dm}^{-3}$; SB: $10.96 \mathrm{cmol}_{\mathrm{c}} \mathrm{dm}^{-3}$; t: $11 \mathrm{cmol}_{\mathrm{c}} \mathrm{dm}^{-3}$; base saturation (V\%): $73 \%$; T: $14.92 \mathrm{cmol}_{\mathrm{C}} \mathrm{dm}^{-3}$, sand: $18 \mathrm{dag} \mathrm{kg}^{-1}$;

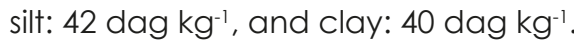

The study was designed in randomized blocks, with four replications, in a $3 \times 5$ factorial scheme. The first factor consisted of three fertilization managements with zinc (2 $\mathrm{kg} \mathrm{ha}^{-1}$, in the form of zinc sulfate): control without zinc; $100 \%$ of the dose applied at sowing, via soil; and $50 \%$ of the dose applied at sowing, via soil, $+50 \%$ of the dose applied at full bloom, via foliar spraying. The second factor corresponded to five doses of phosphorus: 0, 60, 120,180 , and $240 \mathrm{~kg} \mathrm{ha}^{-1}$ of $\mathrm{P}_{2} \mathrm{O}_{5^{\prime}}$ applied at sowing in the form of monoammonium phosphate (MAP).

The cultivation was fertilized with $100 \mathrm{~kg} \mathrm{ha}^{-1}$ of $N$ in the form of urea $145 \%$ of the dose applied at sowing and $55 \%$ applied in topdressing, 30 days after sowing) and $40 \mathrm{~kg} \mathrm{ha}^{-1}$ of $\mathrm{K}_{2} \mathrm{O}$ in the form of potassium chloride, applied at sowing, using as a reference the recommendation proposed by Chagas et al. (1999) for the bean crop, technological level four $\left(\mathrm{NT}_{4}\right)$ since there is still no consolidated fertilization recommendation for chickpea cultivation in the north of Minas Gerais.

The chickpea cultivar used in the experiment was the BRS Aleppo, indicated for cultivation in the dry season, belonging to the Kabuli group and presenting semi-erect growth (Nascimento et al., 2014). Sowing was performed manually, and the plots were composed of four planting rows, spaced $0.5 \mathrm{~m}$ between rows and $0.10 \mathrm{~m}$ between plants. After the opening of the planting groves, the seeds were distributed in a density of 20 seeds per meter, with later thinning and average maintenance of 10 plants per linear meter.

Phytosanitary treatments and irrigation were performed according to the crop requirements and the technical recommendations for the crop in the region (Nascimento et al., 2016). The irrigation system consisted of sprinklers, with an irrigation shift of four days. Whenever necessary, the manual control of weeds was performed.

At the end of the cultivation period, ten plants from the useful plot were evaluated for the characterization of the following production components: 100-grain mass (M100), in grams; mass of pods (MSV) and grains (MSG), expressed in g per plant; total number of pods (NV), in pods per plant; mean number of pods (NMV); number of grains (NG), expressed in grains per plant; total grain mass (MGT), in g per plant; mean grain mass (MMG), in grams; yield (PROD), in $\mathrm{kg} \mathrm{ha}^{-1}$; total shoot dry mass (MSPA), and dry mass of shoot residues (MSRV), in $\mathrm{kg} \mathrm{ha}^{-1}$.

The agronomic efficiency was also estimated, through the following equation:

$$
E A=(P G-P G T e s t) / Q T P
$$

In which:

EA: is the agronomic efficiency index, expressed in kilogram of grains per kilogram of phosphate fertilizer added $\left(\mathrm{kg} \mathrm{kg}^{-1}\right)$;

PG: is the production of grains $(\mathrm{kg})$ with the use phosphate fertilizers;

PGTest: is the production of grains $(\mathrm{kg})$ without the use of phosphate fertilizers (control);

QTP: is the total dose of phosphate fertilizer $(\mathrm{kg}$ $\mathrm{ha}^{-1}$ ) used.

The data were subjected to analysis of variance using the SISVAR 5.3 software (Ferreira, 2011) and, if significant $(p<0.05)$, Dunnett's test was performed for the comparison of the control treatment (without phosphate fertilization) with the phosphate fertilization. The qualitative 
factor (zinc management) was compared by Tukey's test at a $5 \%$ level of probability, and the quantitative factor (doses of phosphorus) was compared through regression models chosen based on the significance of the regression coefficients and the potential to explain the biological phenomenon. For the EA, the descriptive analysis of the data was proposed.

\section{Results and Discussion}

The M100, MTG, PROD, MSPA, and MSRV characteristics were influenced only by the isolated factor doses of $P$ (Table 1). There was no interaction ( $P$ $>0.05$ ) between $\mathrm{Zn}$ management and doses of $P$, and there was an isolated effect of Zn management on the components of chickpea production.

Table 1. Mean Square and Degrees of Freedom (GL) of the 100-grain mass (M100), pod dry mass (MSV), number of pods (NV), number of grains (NG), total grain mass (MTG), yield (PROD), total dry mass (MSPA), and dry mass of plant residues (MSRV) of chickpea after the application of phosphorus doses and zinc management.

\begin{tabular}{|c|c|c|c|c|c|}
\hline \multirow[b]{2}{*}{ FV } & \multirow[b]{2}{*}{ GL } & \multicolumn{4}{|c|}{ Mean square } \\
\hline & & M100 & MSV & NV & NG \\
\hline Block & 3 & $9.656^{\text {ns }}$ & $2.201^{\mathrm{ns}}$ & $272.346^{\text {ns }}$ & $367.636^{\text {ns }}$ \\
\hline Zn management & 2 & $5.001^{\mathrm{ns}}$ & $0.425^{\text {ns }}$ & $25.567^{\mathrm{ns}}$ & $89.022^{\text {ns }}$ \\
\hline Doses of $P$ & 4 & $9.316^{*}$ & $3.805^{\mathrm{ns}}$ & $267.323^{\text {ns }}$ & $306.152^{\text {ns }}$ \\
\hline$Z n \times P$ & 8 & $5.736^{\mathrm{ns}}$ & $1.867^{\mathrm{ns}}$ & $133.048^{\text {ns }}$ & $165.531^{\mathrm{ns}}$ \\
\hline Residue & & 3.099 & 2.138 & 163.863 & 134.178 \\
\hline $\mathrm{CV}(\%)$ & & 4.97 & 47.74 & 33.57 & 32.44 \\
\hline Mean & & 35.45 & 3.06 & 38,13 & 35,71 \\
\hline $\mathrm{FV}$ & GL & MTG & PROD & MSPA & MSRV \\
\hline Block & 3 & $72.412^{\text {ns }}$ & $2488281.71^{\mathrm{ns}}$ & $4424196.59^{\text {ns }}$ & $581456.86^{\mathrm{ns}}$ \\
\hline Zn management & 2 & $18.364^{\mathrm{ns}}$ & $615876.51^{\mathrm{ns}}$ & $1948153.11^{\mathrm{ns}}$ & $303223.06^{\mathrm{ns}}$ \\
\hline Doses of $P$ & 4 & $56.288^{*}$ & $2044790.34^{*}$ & $33039326.60^{* *}$ & $18989883.76^{* *}$ \\
\hline $\operatorname{Zn} \times P$ & 8 & $25.190^{\text {ns }}$ & $936567.09^{\mathrm{ns}}$ & $3821972.06^{\mathrm{ns}}$ & $1880020.99^{\text {ns }}$ \\
\hline Residue & & 19.725 & 733544.30 & 4418851.39 & 1846572.00 \\
\hline $\mathrm{CV}(\%)$ & & 31.80 & 32.22 & 23.68 & 22.34 \\
\hline Mean & & 13.97 & 2658.46 & 8875.38 & 6082.22 \\
\hline
\end{tabular}

The fertilization with $\mathrm{Zn}$ did not influence the chickpea production components (Tables 1 and 2). In this perspective, the characteristics of M100, MSV, NV, NG, MTG, PROD, MSPA, and MSRV presented means corresponding to $35.45 \mathrm{~g}, 3.06 \mathrm{~g}$ per plant, 38.13 pods per plant, 35,71 grains per plant, 13.97 grains per plant, 2.658,46 $\mathrm{kg} \mathrm{ha}^{-1}, 8.875,38 \mathrm{~kg} \mathrm{ha}^{-1}$, and 6.082,22 $\mathrm{kg} \mathrm{ha}^{-1}$, respectively (Table 2). The absence of response of fertilization to $\mathrm{Zn}$ management on the chickpea production components was attributed to the high natural fertility and the presence of a higher content of organic matter in the soil (7.37 dag $\mathrm{kg}^{-1}$ ), implying in greater natural availability of $\mathrm{Zn}$ for the plants, during cultivation. However, Haider et al. (2018), when studying Zn doses in Vigna radiata L., in Pakistan, verified that the application of $10 \mathrm{mg}$ of $\mathrm{Zn}$ per kilogram of soil provided a higher number of grains per plant (4.63), harvest index (31.11\%), and Zn content on the grain (42.03 $\mathrm{mg} \mathrm{kg}^{-1}$ ). The authors highlighted the importance of the application of this micronutrient, indicating that its role in the plant may have reinforced the increase of protein synthesis, $\mathrm{N}$ metabolism, and cell division, which consequently resulted in higher yields. In Ethiopia, Hidoto et al. (2017) evaluated chickpea varieties and $\mathrm{Zn}$ application managements $\left(8 \mathrm{~kg} \mathrm{ha}^{-1}\right)$ in the form of Zn sulfate and verified a higher Zn content on the grains when performing foliar application. However, the authors obtained no difference in grain yield and growth, with a mean yield of $1.880 \mathrm{~kg} \mathrm{ha}^{-1}$.

Table 2. 100-grain mass (M100), pod dry mass (MVG), number of pods (NV), number of grains (NG), total grain mass (MTG), yield (PROD), total dry mass (MSPA) and dry mass of plant residues (MSRV) of chickpea after fertilization management without Zn, with Zn at sowing and in topdressing (Zn-Sem and Cob), and with Zn application at sowing only (Zn-Sem).

\begin{tabular}{ccccc}
\hline Characteristic & Without Zn & Zn-Sem and Cob & Zn-Sem & Mean \\
\hline M100 (g) & $35.96 \mathrm{a}$ & $35.42 \mathrm{a}$ & $34.96 \mathrm{a}$ & 35.45 \\
MSV (g per plant) & $3.14 \mathrm{a}$ & $2.89 \mathrm{a}$ & $3.16 \mathrm{a}$ & 3.06 \\
NV (pods per plant) & $37.29 \mathrm{a}$ & $39.42 \mathrm{a}$ & $37.68 \mathrm{a}$ & 38.13 \\
NG (grains per plant) & $34.83 \mathrm{a}$ & $38.12 \mathrm{a}$ & $34.18 \mathrm{a}$ & 35.71 \\
MTG (g per plant) & $13.81 \mathrm{a}$ & $14.99 \mathrm{a}$ & $13.10 \mathrm{a}$ & 13.97 \\
PROD (kg ha & $2615.08 \mathrm{a}$ & $2851.56 \mathrm{a}$ & $2508.74 \mathrm{a}$ & 2558.46 \\
MSPA ( $\left.\mathrm{kg} \mathrm{ha}^{-1}\right)$ & $8786.40 \mathrm{a}$ & $9222.31 \mathrm{a}$ & $8617.43 \mathrm{a}$ & 8875.38 \\
MSRV (kg ha & $6025.22 \mathrm{a}$ & $6223.53 \mathrm{a}$ & $5997.93 \mathrm{a}$ & 6082.22 \\
\hline
\end{tabular}

Means followed by the same letter in the row do not differ from each other by Tukey's test at $5 \%(\mathrm{p}<0.05)$ 
The $P$ doses provided the increase of the NG, MTG, MSPA, MSRV, and PROD when compared to the control (Table 3). The NG, MTG, PROD, MSPA, and MSRV were incremented by $29,35,34,48$, and $55 \%$, respectively, with the application of $\mathrm{P}$ doses (Table 3 ). The mean yield and the production of shoot dry matter, after the application of $\mathrm{P}$, corresponded to $2.802,97$ and $9.496,39$ $\mathrm{kg} \mathrm{ha}^{-1}$, respectively, indicating an increase in grain yield and biomass production by the plant in response to the low natural availability of $P$ in the soil.

It is known that most of the Brazilian tropical soils present low or very low natural availability of phosphorus to the plants (Novais \& Smyth, 1999). In these soils, the balanced application of phosphorus becomes of utter importance for chickpea growth and production increase. Pegoraro et al. (2018) obtained a chickpea yield of $2.710 \mathrm{~kg} \mathrm{ha}^{-1}$ when using $200 \mathrm{~kg} \mathrm{ha}^{-1}$ of $\mathrm{P}$ in the semiarid region of Minas Gerais. Wolde-Meskel et al.
(2018), in Ethiopia, verified an increase in chickpea yield of $413 \mathrm{~kg} \mathrm{ha}^{-1}$ when using $P$ compared to the control treatment without application of $23 \mathrm{~kg} \mathrm{ha}^{-1}$ of $\mathrm{P}$. In spite of the difference in $\mathrm{P}$ quantities, the importance of this nutrient for yield increase in this legume species is evident.

The phosphate fertilization also increased the production of chickpea plant residues (MSRV) (Table 3), characterizing a greater deposition of vegetal remains from cultivation in the soil per unit of biomass accumulated in the shoot part. This fact contributes to the increase in the cycling of nutrients and organic matter in the soil. The higher grain production associated to the increase in the production of plant residues after phosphate fertilization is related to the several roles that this nutrient performs since this macronutrient is a component of nucleic acids and coenzymes, directly influencing energy storage in the plant (Taiz et al., 2017; Marschner, 2012).

Table 3. 100-grain mass (M100), pod dry mass (MSV), number of pods (NV), number of grains (NG), total grain mass (MTG), yield (PROD), total shoot dry matter (MSPA) and dry mass of plant residues (MSRV) of chickpea after fertilization with $P$ and without $P$ application.

\begin{tabular}{cccc}
\hline Characteristics & Without P & P Doses & Mean \\
\hline M100 (g) & $34.06 \mathrm{a}$ & $35.80 \mathrm{a}$ & 34.93 \\
MSV (g per plant) & $2.10 \mathrm{a}$ & $3.27 \mathrm{a}$ & 3.73 \\
NV (pods per plant) & $32.23 \mathrm{a}$ & $39.60 \mathrm{a}$ & 35.90 \\
NG (grains per plant) & $29.08 \mathrm{~b}$ & $37.36 \mathrm{a}$ & 33.22 \\
MTG (g per plant) & $10.91 \mathrm{~b}$ & $14.73 \mathrm{a}$ & 12.82 \\
PROD (kg ha-1) & $2080.41 \mathrm{~b}$ & $2802.97 \mathrm{a}$ & 2441.69 \\
MSPA (kg ha-1) & $6391.36 \mathrm{~b}$ & $9496.39 \mathrm{a}$ & 7943.87 \\
MSRV (kg ha-1) & $4208.48 \mathrm{~b}$ & $6550.66 \mathrm{a}$ & 5379.57 \\
Percentage of MSRV & 66 & 69 & \\
\hline
\end{tabular}

The $\mathrm{P}$ doses linearly increased the 100-gran mass, grain mass, yield, and total and residual dry matter production, with values of $36.33 \mathrm{~g}, 15.67 \mathrm{~g} \mathrm{plant}^{-1}, 3018.3 \mathrm{~kg}$ $\mathrm{ha}^{-1}, 10731.8 \mathrm{~kg} \mathrm{ha}^{-1}$, and $7556.06 \mathrm{~kg} \mathrm{ha}^{-1}$, respectively, at the highest dose $\left(240 \mathrm{~kg} \mathrm{ha}^{-1}\right.$ ) of $\mathrm{P}_{2} \mathrm{O}_{5}$ (Figure 1), indicating a high response of the crop to phosphate fertilization in tropical soils with low natural availability of this nutrient. Wolde-Meskel et al. (2018) obtained an increase in the proportion of $20.8 \%$ in chickpea production with the application of a $23 \mathrm{~kg} \mathrm{ha}{ }^{-1}$ dose of $\mathrm{P}_{2} \mathrm{O}_{5}$, with a mean grain yield of $1.943 \mathrm{~kg} \mathrm{ha}^{-1}$ with the application of $\mathrm{P}$ and $1.611 \mathrm{~kg} \mathrm{ha}^{-1}$ without $\mathrm{P}_{2} \mathrm{O}_{5}$ application. Also, Badini et al. (2015), when evaluating the chickpea varieties D.G-92 and D.G-89, obtained a maximum yield of $1851.20 \mathrm{~kg} \mathrm{ha}^{-1}$ after the application of $55 \mathrm{~kg} \mathrm{ha}^{-1}$ of $\mathrm{P}_{2} \mathrm{O}_{5^{\prime}}$ evidencing the increment effect in grain production according to the increase in the application of phosphorus.

In spite of the linear increment in the yield and production of shoot dry matter in chickpea, with the increase of the $\mathrm{P}$ doses, the highest EA was obtained with the use of the lowest $\mathrm{P}$ dose $\left(60 \mathrm{~kg} \mathrm{ha}^{-1}\right.$ of $\left.\mathrm{P}_{2} \mathrm{O}_{5}\right)$ in association with $\mathrm{Zn}$, either through $100 \%$ at sowing or divided into sowing and topdressing, compared to the absence of Zn fertilization (Figure 2). This indicates a greater phosphorus-use efficiency by the chickpea crop with the use of a lower $\mathrm{P}$ dose associated with the fertilization with Zn. In other plants species, such as wheat, there was a yield increase after the application of $P$ and $Z n$ at the doses of $75 \mathrm{mg} \mathrm{kg}^{-1}$ and $5 \mathrm{mg} \mathrm{kg}^{-1}$ of soil, respectively, for providing a positive effect in the metabolism, resulting in normal plant growth (labal et al., 2017).

The reduction in the EA at the highest $\mathrm{P}$ doses can be justified by the greater availability of $P$ in the soil, allowing greater absorption and accumulation of this element in the shoot part of the plants (Zhang et al., 2017). Similar results were found by Fageria \& Barbosa Filho (2007) when observing the greater agronomic and physiological efficiency in rice cultivation after the application of lower doses of $P$. 


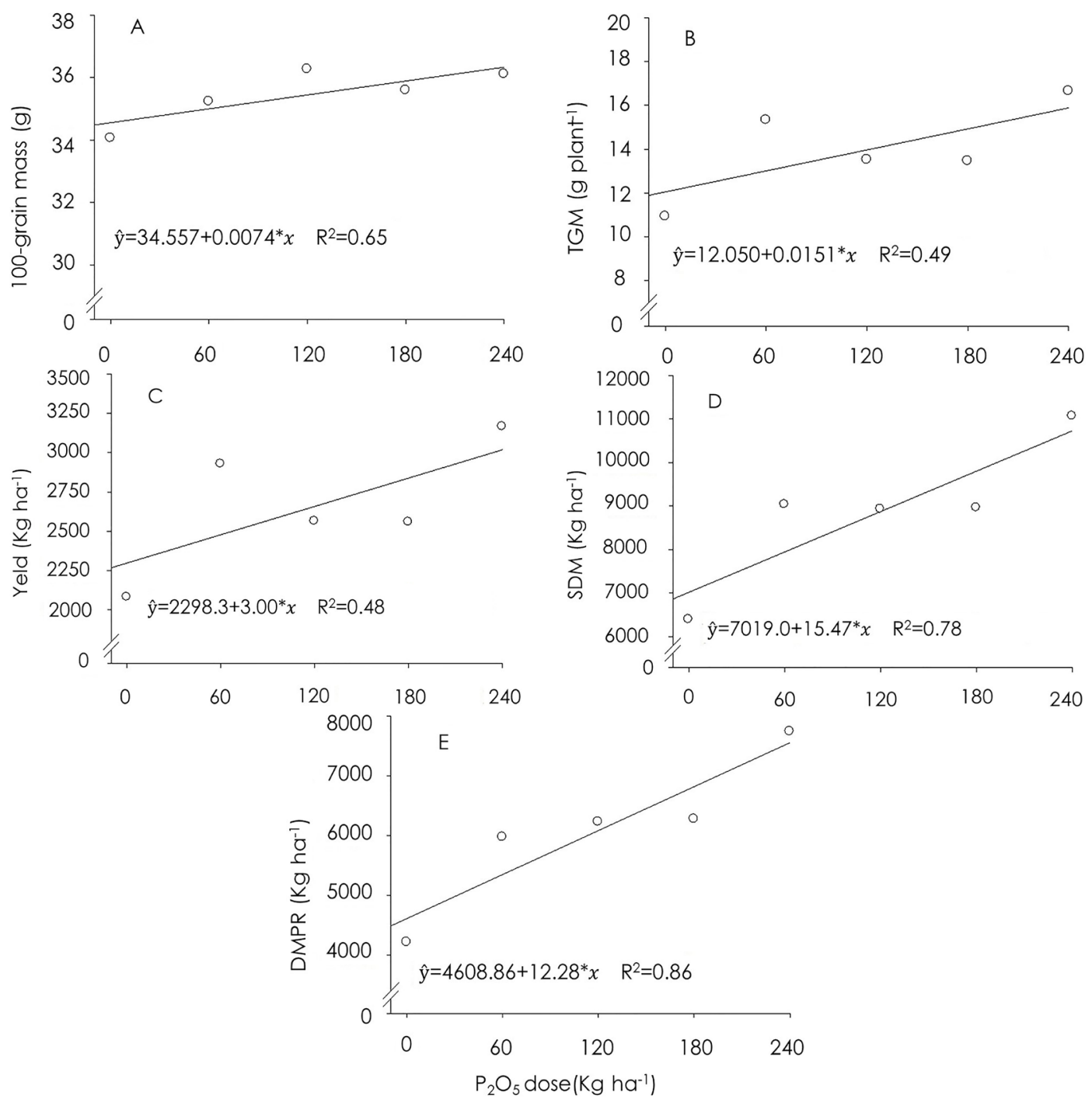

Figure 1. 100-grain mass (A), total grain mass-TMG (B), yield (C), shoot dry mass- SDM (D), and dry mass of plant residues -DMPR (E) after the application of phosphorus doses in chickpea cultivation.

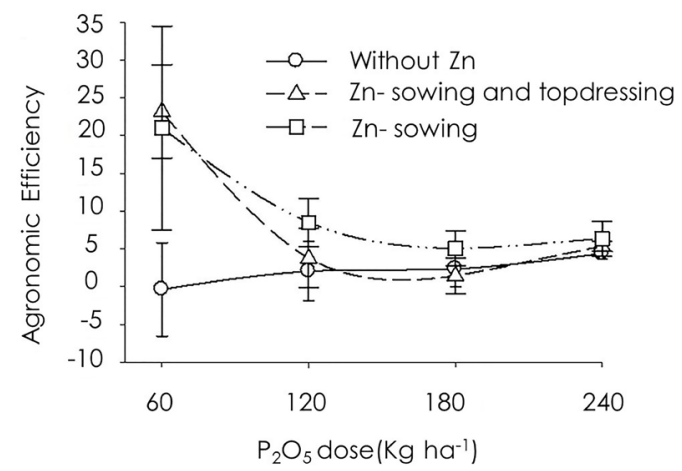

Figure 2. Agronomic efficiency index for the chickpea crop after fertilization with doses of $P$ and fertilization management with Zn.

Although the managements with zinc presented similar EA, its application only at sowing can be preferentially adopted in chickpea cultivation due to the lower operational cost when compared with the parceled application of zinc parceled into $50 \%$ at sowing and $50 \%$ at the beginning of flowering, since the latter requires a greater number of field operations, machinery employment, and manpower.

\section{Conclusions}

The application of $\mathrm{P}$ and $\mathrm{Zn}$ does not interfere with the production components of pod weight, number of pods, and number of chickpea grains. 
The application of $\mathrm{P}$ doses linearly increases the production of chickpea dry matter, grain mass, and yield.

The application of $240 \mathrm{~kg} \mathrm{ha}^{-1}$ provides a yield of $3.018 \mathrm{~kg} \mathrm{ha}^{-1}$ and increments by $720 \mathrm{~kg} \mathrm{ha}^{-1} \mathrm{compared} \mathrm{to}$ the control treatment, without phosphorus addition.

The highest agronomic efficiency (EA) for chickpea is obtained with the application of $60 \mathrm{~kg} \mathrm{ha}^{-1}$ of $\mathrm{P}_{2} \mathrm{O}_{5}$ and $2 \mathrm{~kg} \mathrm{ha}^{-1}$ of $\mathrm{Zn}$ in a single dose, at sowing.

\section{Acknowledgments}

The authors tank thehe Minas Gerais Research Funding Foundation (FAPEMIG), Pro-Rectory Research of Federal University de Minas Gerais (PRPq -UFMG) and the National Council for Scientific and Technological Development (CNPq) for the financial support and the scholarships granted to the authors.

\section{References}

Artiaga, O.P., Spehar, C.R., Boiteux, L.S., Nascimento, W.M. 2015. Avaliação de genótipos de grão de bico em cultivo de sequeiro nas condições de Cerrado. Revista Brasileira Ciências Agrárias 10: 102-109.

Avelar, R.I.S., Costa, C.A., Brandão Júnior, D.S., Paraíso, H.A., Nascimento, W.M. 2018. Production and quality of chickpea seeds in different sowing and harvest periods. Journal of Seed Science, 40: 155-164.

Badini, S.A., Khan, M., Baloch, S.U., Baloch S.K., Baloch, H.N., Bashir, W., Badini, A.R., Badini, M.A. 2015. Effect of phosphorus levels on growth and yield of chickpea (Cicer aretinum L.) varieties. Journal of Natural Sciences Research 5: 2224-3186.

Balai, K., Sharma, Y., Jajoria, M., Deewan, P., Verma, R. 2017. Effect of phosphorus, and zinc on growth, yield and economics of chickpea (Cicer aritinum I.). International Journal of Current Microbiology and Applied Sciences 6: 1174-1181.

Canci, H., Toker, C 2009. Evaluation of yield criteria for drought and heat resistance in chickpea (Cicer arietinum L.). Journal of Agronomy and Crop Science 195: 47-54.

Chagas, J., Braga, J., Vieira, C., Salgado, L., Junqueira Neto, A., Araújo, G., ... \& Ribeiro, A. 1999. Recomendação adubação para o feijão. In: Ribeiro, AC; Guimarães, P.T., Alvarez, V.H. Recomendações para o uso de corretivos e fertilizantes em Minas Gerais $5^{\circ}$ Aproximação. Comissão de fertilidade do solo do estado de Minas Gerais, Viçosa, Brazil. p. 306-308.

Fageria, N.K., Barbosa Filho, M. 2007. Dry-matter and grain yield, nutrient uptake, and phosphorus use-efficiency of lowland rice as influenced by phosphorus fertilization. Communications in soil science and plant analysis 38: 1289-1297.

FAO. Food and Agriculture Organization of the United Nations. 2017. http://faostat3. fao.org/faostat-gateway/ go/to/home/E/ <Access on 10 Jan. 2019>
Ferreira, D.F. 2011 . Sisvar: a computer statistic alanalysis system. Ciência e Agrotecnologia 35: 1039-1042.

Haider, M.U., Hussain, M., Farooq, M., Nawaz, A. 2018. Soil application of zinc improves the growth, yield and grain zinc biofortification of mung bean. Soil and Environment 37: 123-128.

Hidoto, L., Worku, W., Mohammed, H., Bunyamin, T. 2017. Effects of zinc application strategyon zinc content and productivity of chickpea grown under zinc deficient soils. Journal of Soil Science and Plant Nutrition 17: 112-126.

Hoskem, B.C.S., Costa, C.A., Nascimento, W.M., Santos, L.D.T., Mendes, R.B., Menezes, J.B.C. 2017. Productivity and quality of chickpea seeds in Northern Minas Gerais, Brazil. Revista Brasileira de Ciências Agrárias 12: 261-268.

labal, M.M., Murtaza, G., Mehdi, S.M., Naz, T., Farooq, O., Ali, M., Du Laing, G. 2017. Evaluation of phosphorus and zinc interaction effects on wheat grown in saline-sodic soil. Pakistan Journal of Agricultural Sciences 54: 531-537.

Laranjo, M., Alexandre, A., Oliveira, S 2014. Legume growthpromoting rhizobia: An overview on the Mesorhizobium genus. Microbiological Research, 169: 2-17.

Marschner, P. 2012. Marschner's mineral nutrition of higher plants. Academic press, Amsterdã, Netherlands. 649 p.

Nascimento, W.M., Artiaga, O., Boiteux, L., Suinaga, F., Reis, A., Pinheiro, J., Spehar, C. 2014. BRS Aleppo: grãode-bico. Maior tolerância a fungos de solo. Embrapa Hortaliças, Brasília, Brazil. 4 p. Boletim Técnico.

Nascimento, W.M., Silva, P., Artiaga, O., Suinaga, F.A. 2016. Grão-de-bico. In: Nascimento, W.M. (ed) Hortaliças leguminosas. Embrapa Hortaliças, Brasília, Brazil. p. 89118.

Neenu, S., Ramesh, K., Ramana, S., Biswas, A.K., Rao, A.S. 2014. Growth and yield of different varieties of chickpea (Cicer arietinum L.) as influenced by the phosphorus nutrition under rainfed conditions on Vertisols. International Journal of Bio-resourceand Stress Management 5: 053057.

Novais, R.F., Smyth, T.J. 1999. Fósforo em solo e planta em condições tropicais. Universidade Federal de Viçosa, Viçosa, Brazil. 399 p.

Pegoraro, R.F., Almeida Neta, M.N., Costa, C.A., Sampaio, R.A., Fernandes, L.A., Rodrigues, M.N. 2018. Chickpea production and soil chemical atributes after phosphorus and molybdenum fertilization. Ciência e Agrotecnologia 42: 474-483.

Taiz, L., Zeiger, E., Møller, I.M., Murphy, A. 2017. Fisiologia e desenvolvimento vegetal. 6.ed. Artmed Editora, Porto Alegre, Brazil. 858 p.

Vilar, C.C., Costa, A.C.S., Hoepers, A., Souza Junior, I.G.D. 2010. Capacidade máxima de adsorção de fósforo relacionada a formas de ferro e alumínio em solos subtropicais. Revista Brasileira de Ciência do Solo 34: 1059-1068. 
Wolde-Meskel, E., Heerwaarden, J.V., Abdulkadir, B., Kassa, S., Aliyi, I., Degefu, T., Giller, K.E. 2018. Additive yield response of chickpea (Cicer arietinum L.) to rhizobium inoculation and phosphorus fertilizer across mallhol de rfarms in Ethiopia. Agriculture, Ecosystems \& Environment 261: 144-152.

Zhang, W., Chen, X.X., Liu, Y.M., Liu, D.Y., Chen, X.P., Zou, C.Q. 2017. Zinc uptake by roots and accumulation in maize plants as affected by phosphorus application and arbuscular mycorrhizal colonization. Plant and soil 413: 5971.

Conflict of Interest Statement: The authors declare that the research was conducted in the absence of any commercial or financial relationships that could be construed as a potential conflict of interest.

All the contents of this journal, except where otherwise noted, is licensed under a Creative Commons Attribution License attribuition-type BY. 